\title{
The Effect of Product Knowledge on Salesperson Performance with the moderating role of Attitude
}

\author{
Hotlan Siagian ${ }^{1 *}$, Garry Putera ${ }^{1}$, and Juris Burlakovs ${ }^{2}$ \\ ${ }^{1}$ Faculty of Business and Economics, Petra Christian University, Jl. Siwalankerto 121-131, \\ Surabaya, 60236, Indonesia. \\ ${ }^{2}$ Estonian University of Life Sciences, 51014 Tartu, Estonia
}

\begin{abstract}
This Study investigate The Effect of Product Knowledge on salesperson Performance with the moderating Role of Attitude. Amout of 65 from 72 questionnaires are considered valid for further analysis. Data analysis used Partial Least Square (PLS) with the smartPLS software version 3.0. Data analysis was performed to assess the measurement model and the inner model. The result revealed that one hypothesis was supported and the other one was not supported. Product knowledge influence the salesperson performance while attitude did not moderate the influence of product knowledge on the salesperson performance. This result of study enhances the insight of the sales manager that attitude did not moderate the salesperson performance. Manager needs to review the training of the salesperson in order the attitude contribute to the salesperson performance.
\end{abstract}

Keywords: Customer satisfaction, employee knowledge, sales achievement.

\section{Introduction}

In today's era of global economic, the company should perform their best efforts in providing the best service to its consumers. The competition is an inseparable part of life of a company's activities. A company should have an appropriate competitive strategy to outperform the competitors. Among the resources, qualified human resources become one the most important of the resources required by a company to win the competition. The empowerment of quality human resources enables the company to achieve the company targets. Having enough quality human resources enable all function of the organization to synergy in the pursue of the company best performance. Qualified salespersons allow the company to achieve the target. Qualified salesperson resources, generate high sales volume, and achieve the company's targets. The majority of companies fail and cannot survive due to poor employee performance, which results in cross-functional synergies not going well. This situation makes the company unable to compete, and adapt to the uncertain and dynamic environment. The performance of human resources is very essential in achieving company goals. A research by [1] suggest that tenacious salesperson is described as the person who is committed to meeting the needs of customers. Besides, the success of a

*Corresponding author: hotlan.siagian@petra.ac.id 
company can be seen from the quality of the relationship built between salesperson and customers as a team. Many sales management experts and salesperson advise that these conditions will be achieved if the company can maintain the attitude of salesperson to attract customers. Attitude plays a vital role in improving salesperson performance.

Work attitude is the regularity of one's feelings and thoughts and the tendency to act on aspects of the environment. Every employee has their way of addressing the problems they face [2]. However, the company should take part in resolving the situation to create a conducive atmosphere and work environment so that employees can respond positively, and salesperson can improve their performance. Knowledge has become a strategic asset for a company. Companies that invest in knowledge assets and values become more successful compared to companies that do not invest in knowledge. Product knowledge is an essential element in strengthening the strategic role of salesforce. Product knowledge is often a critical factor that determines the interaction between salesperson and customers [3]. The mastery of salesperson over all of the company's product attributes is a definite form of assessment. For customers, the product knowledge of the salesperson is a reflection of the quality of the salesperson. The lack of product knowledge possessed by salesperson will result in difficulties or significant obstacles in the process of adjusting to the sales situation. Inadequate information obtained by customers from salesperson will cause the customers to reconsider before purchasing the products offered [1]. Therefore, a salesperson should understand the attribute and function of the products being offered, starting from the very basic to the most advanced properties of the product. Salesperson can deliver an added value to the customers by mastering the products knowledge. Furthermore, the way how the salesperson communicate the product knowledge, in the end, requires a right attitude in order the prospective customers get convinced and more confident about the products. Conversely, if the salesperson does not understand the attributes of the product sold, it will result in the customer not interested in buying the product offered. In other words, the attitude of the salesperson can weaken or strengthen influence.

Based on the discussion and background above, this study aim at examines the effect of product knowledge on salesperson performance with Attitude of the salesperson as a moderating variable. Thus this research raised two research questions, namely: i) whether product knowledge affects salesperson performance, ii) whether attitude moderates the relationship between product knowledge and salesperson performance. This research contributes to enrich the insight of the manager in the properties industry. This study also contributes to the on-going research in the business management.

\section{Theoretical review}

\subsection{Product knowledge}

Product is a primary element in a marketing program. The products the company sells determines the marketing strategy and the competitive strategy of the company. Purchasing a product by the customer is not just to own the product but also to meet the needs and desires of consumers. According to [4] the definition of a product is any product that can be offered to the market to satisfy the wants or needs of customers. The product is defined as a complex trait, both tangible and intangible, including packaging, color, price, company and retailer prestige. Products are also defined as tangible objects or intangibles that can be bought by consumers. From the above definition it can be concluded that the product is everything created by the company so that it can be offered to get attention in satisfying the wants and needs of consumers [5]. Knowledge is defined as knowledge acquired by someone in the form of knowledge that can be stored as memory. Knowledge is a collection of concepts, principles, information obtained through learning or experience. Knowledge is everything we know. There are two types of knowledge, namely factual knowledge, in the form of information that we receive as reality and experiential knowledge, namely the understanding that we obtain comes from a person's experience [6]. The breadth of insight 
or knowledge is one of the requirements so that a person can optimally and productively work and improve the quality of his life. Product knowledge is conceptually essential to consumers and is influenced by information gathering from marketers [7]. Product knowledge means that a person must know in advance whether he understands all the attributes of the product or service he sells. This includes how the product works, its application, installation, and price options [8]. Knowledge about the product is indeed needed for the salesperson. At least, with the knowledge of the product, salesperson has the ability to answer almost all customer questions about the product, so consumers feel happy and are interested in buying products or using the services offered.

The diversity and dynamics of customer needs and expectations require a salesperson to know the diversity of the company's product line, the benefits of the company's products, to the specialty of the company's products when compared to competitors' products. Product knowledge makes and shapes the mental attitude to be more ready in selling products. Product knowledge also makes salesperson carry out marketing activities as a source of information for consumers and vice versa for salesperson. Thus, product knowledge has become an essential factor that determines the seller's performance. Through product knowledge, salesperson can adapt sales force more directly and with high self-confidence can lead to more valued in the eyes of consumers, so the opportunity to adapt to salesperson will be higher. There are three indicators to measure product knowledge, namely i), subjective knowledge refers to how much someone knows about a product or what is also commonly referred to as self-assessed knowledge, ii) objective knowledge, which refers to how much the level and type of information contained in a person's memory, iii) experience-based knowledge refers to how much someone's experience regarding the product concerned [9]. The more significant experience the salesperson has, the more effective the work he is undertaking.

\subsection{Attitude}

Attitude is evaluative statements, both desirable or undesirable, regarding objects, people, or events [10]. Attitude is an evaluation, feeling and tendency of someone who is relatively consistent with an object or idea, in other words, attitude is a feeling that arises in a person towards an object, both before and after people see, feel, and enjoy the object [11]. Attitude as a tendency based on what is obtained from consistent learning outcomes, which shows the likes or dislikes of an object [12]. Attitude as a way of placing or carrying oneself, or a way of feeling, way of thinking, and behavior [13]. Based on some of the definitions above, it can be concluded that attitude is a complex mental condition that involves beliefs and feelings, and disposition to act in a certain way. Attitudes reflect how someone does something, carry oneself, or how to feel someone. The attitude is the mental condition of a person that is gained from experience, which directs and dynamically influences individual responses to all objects and related situations [14]. The attitude indicators are flexible and free-thinking in thinking, freedom of expression, interest in creative activities, belief in one's ideas, and involvement in tasks [15].

\subsection{Salesperson Performance}

Provides an understanding that performance or work performance is the level of overall success of a person during a specific period in carrying out the task compared with various possibilities, such as work standards, targets, or criteria that have been determined in advance and agreed upon [16]. The performance means they achievement of a worker, a process activity of an organization as a whole, where the results of the work must be demonstrated concretely and measurably [17]. Performance comes from the word job performance or actual performance, which is generally defined as result of work or actual achievement by someone. Performance as the results or overall level of success of a person 
during a specific period in carrying out the task, compared with various indicators such as work standards, targets that have been previously determined and agreed upon [18]. The performance is basically what employees do or do not do. Performance as a picture of the level of achievement of the implementation of activities or policies in realizing the goals, objectives, vision, and mission of the organization as outlined through the strategic planning of an organization [19].

The performance comes from the word performance, which means work results or work performance. However, it should be understood that the performance is not just the result of work or work performance, but also includes how the work process takes place [20]. Based on the understanding of the performance of some of the opinions of the experts, it can be concluded that the performance is the overall activities undertaken to improve the performance of the company or organization, including the performance of each individual and workgroup within a company produced by the functions or indicators of a work in a certain amount of time. There are several opinions regarding the factors that affect employee performance. The factors that influence performance include the ability factor and motivation factor [21]. Every company must be able to compete and keep abreast of developments in winning market competition. This situation encourages companies to implement new strategies in the company's sales management; for this reason a highperformance sales force is needed [22]. At present, it is not uncommon for companies to spend enormous resources to implement strategies, especially in the sales force as a marketing channel in achieving company goals. The success of salesperson is also related to sales performance. The sales performance is the result of the implementation of various sales strategies carried out by the company [23].

Salesperson performance is highly dependent on how marketing strategies are developed because the goal of marketing strategies is how to allocate and coordinate resources effectively and efficiently [24]. Salesforce performance is an achievement of all forms of efforts made by salesperson in determining the right choice and strategic direction. The choice and direction of the right strategy is the key to achieving the expected performance. Salesperson performance can be defined as work results in quality and quantity achieved by someone in carrying out their duties following the responsibilities given to him. Salesperson performance as a form of evaluation and salesperson contributions to achieve organizational goals [25]. The performance of salesperson is one of the critical aspects in evaluating overall organizational performance. That is because the sales force is part of the organization as a whole, which plays an essential role in selling the company's products or services.

Salesperson performance is conceptually useful for testing performance regarding attitudes or activities carried out by salesperson, as well as the results that can be distributed to their businesses [26]. Salesperson performance can be seen from the final results such as sales volume, market penetration, and achieving sales quotas [27]. Salesperson performance is an evaluation of the contribution of salesperson in achieving organizational goals in the form of sales results obtained by accepting salesperson's efforts. In the end, salesperson performance is defined as the ultimate goal of a sustainable strategy between the company and salesperson as measured through specific indicators [28]. The performance of business salesperson based on objective and subjective measurements consisting of sales volume, growth in number of customers, and sales growth [23].

\subsection{Relationship between product knowledge and salesperson performance}

The salesperson is the liaison between the company and the consumer since the consumers will ask about the specifications of a product, and the salesperson should be able to provide an understanding of the product to consumers. The salesperson need to know what product will be conveyed, how deep, and what approaches will be used when conveying this information to consumers [29]. A salesperson needs to know the products explicitly for an excellent two-way communication with consumers. To produce an excellent performance, 
the company needs a good system. This system is not only the regulations or standards that exist but also involves the parties directly related to the human resources. Individual performance is influenced by knowledge, skills, and motivation. Therefore, the company requires the management treat the knowledge of all employees as company assets. This can be done by applying knowledge management, where one component in knowledge management is the mastery of a product knowledge. The leveraging of product knowledge becomes a solution in solving the problems of the performance of their employees, with the final result to achieve the goals and vision that they expect. The experience had a positive effect on sales performance [30]. The main components in the product knowledge help salesperson achieve their goals and vision. It also relates to the performance of salesperson, where the salesperson is the primary driver of a company. When the salesperson's performance is excellent, the organizational performance is also excellent. Therefore, companies need to know the extent to which product knowledge plays a role in improving the performance of salesperson. Based on the above argument, the first hypotheses is proposed as follows:

H1: Product knowledge influences salesperson performance

\subsection{The moderating role of attitude on the product knowledge and sales- person performance relationship}

Characteristics of a salesperson are defined as attributes attached to a person that reflect the quality of a salesperson. The main issue in the characteristics of salesperson lies in personality, attitudes, perceptions, motivation, and satisfaction in sales performance. A positive employee attitude will encourage positive performance. Employees who have positive thoughts about their work, have positive feelings, and act positively will improve their performance. The attitude has a positive moderation effect on product knowledge and employee performance [15]. The employee attitudes and knowledge positively have a strong moderation effect on employee performance. The attitude that exists in a person will give color or style to the behavior or actions of the person concerned. Attitude determines how people view the work environment, interact with others, and behave at work. Someone with a positive work attitude will like his job and solve problems at work happily, while someone with a negative attitude does not show much enthusiasm and commitment to solving problems. With the existence of work attitudes and good employee knowledge of the company, it will encourage employees to work better [31]. Furthermore, when knowledge of a person's product is sufficient and is equipped with one's awareness to show a right attitude, one's performance will be better too. Hence, the second hypotheses is as follow:

$\mathrm{H} 2$ : Attitude moderates the influence of product knowledge on salesperson performance

\section{Research methods}

\subsection{Population and Sample}

This research use quantitative method to analyze the primary data obtained from the respondents. Data collection used questionnaire designed with five-point Likert scale starting from 1: strongly disagree up to 5: strongly agree. A quantitative research is an approach adopted to test the hypotheses of theory by examining the relationships between concepts. The questionnaires were distributed to the respondents through direct delivery by the author. The respondents are the salespersons of the property company in Surabaya PT Intiland Grande. The population are those salesperson working on eight project with the 
total number of 72 salespersons. Based on this number of population, at least 62 respondents are required based on the Slovin formula.

\subsection{Operational definition}

Product knowledge indicator (X1) in this study namely: (i) Salesperson possess adequate knowledge about the product specification, (ii) Salesperson is capable of delivering the information about the product offered in detailed iii) Salesperson own adequate experienced in selling the product [9]. Whereas attitude (X2) is measured namely: (i) thinking flexible and free, (ii) freedom of expression, (iii) very interested in creative activities, (iv) belief in one's ideas, (v) Flexibility of the salesperson help salesperson solve the problem, and vi) involvement in tasks [15]. The construct of Salesperson performance (Y) using the indicators of (i) sales volume, (ii) customer growth, (iii) customer satisfaction, (iv) ability to listen to customers, (v) ability to make sales presentations, (vi) handling customer needs and desires effectively, (vii) creating mutual respect in every sale activity, (viii) sell to prospective customers and sales growth [23].

\subsection{Data collection}

Data collection in this study was carried out through questionnaires, a set of questions to be answered by respondents. The questionnaire was distributed to the salesperson of eight project owned by PT Intiland Grande Surabaya, a property company domiciled in Surabaya. The population are those salespersons working on eight project with the total number of 72 salespersons. For further validity analysis, this research considered 65 questionnaires from 72 total samples. Then the data analysis uses Partial Least Square (PLS) with the help of smartPLS software version 3.0. Data analysis was performed to assess the measurement model and test the research hypotheses. Assessment of the measurement model is done by looking at the validity and reliability while testing the hypothesis is done by looking at the t-statistic value of each path coefficient of the inner model. A measurement model is accepted with the terms convergent validity, and discriminant validity meet specific values while relativity is fulfilled when the composite reliability and Cronbach values are negligible. Test the research hypothesis with the t-test where the hypothesis is accepted if $t$ arithmetic $<1.96$ with a significance level of $5 \%$

\section{Analysis and results}

Respondents in this study were all salespersons from PT Intiland Grande Surabaya. Table 1 shows the identity of the study respondents, which consisted of gender, age, length of work, and the project handled. From the data collected, it was obtained that the majority of respondents, as many as 46 people or $70.8 \%$ were male, and only 19 people or $29.2 \%$ were women. Based on the length of work of respondents it is known that the majority of respondents have worked between $1 \mathrm{yr}$ to $5 \mathrm{yr}$, i.e., as many as 36 respondents or $55.4 \%$, then 21 respondents or $32.3 \%$ have worked less than $1 \mathrm{yr}$, as many as seven people or $10.8 \%$ of respondents have worked between $6 \mathrm{yr}$ to $10 \mathrm{yr}$, and the rest for respondents who have worked more than $10 \mathrm{yr}$ amounted to one person or $1.5 \%$. Table 1 shows that the majority of respondents handled the Rosebay project with 18 respondents or $27.7 \%, 1$ 7 people or $26.1 \%$ respondents handled the Graha Golf project, and as many as eight people or $12.3 \%$, handled the project Retail. 
Tabel 1. Project handled bay respondent

\begin{tabular}{lcc}
\hline Project handled & No.of Salespersons & Percentage \\
\hline The Rosebay & 18 & $27.7 \%$ \\
Graha Golf & 17 & $26.1 \%$ \\
Retail & 8 & $12.3 \%$ \\
Graha Natura & 7 & $10.8 \%$ \\
Spazio Tower & 5 & $7.7 \%$ \\
Spazio & 4 & $6.2 \%$ \\
Sumatra36 & 4 & $6.2 \%$ \\
Praxis & 2 & $3 \%$ \\
\hline Total & 65 & $100 \%$ \\
\hline
\end{tabular}

Assignment of the salespersons on each projects is based on the size of the project being handled. Whereas the Praxis project has the smallest number of salesperson compared to other projects, on the basis that the Praxis project is the most recent project being released by PT Intiland Grande, so it does not require as many salesperson as other project requirement.

\subsection{Descriptive analysis}

Descriptive statistics in this study use average statistics (mean), which illustrate the average value of all respondents statement. The mean class interval aims to find out where the average rating of respondents for each variable in question with a range of scales [3]. The following is the respondent's response to the statement contained in the product knowledge variable. Table 2 above states that, in general, the respondents already have excellent product knowledge. This is evidenced from the mean number of 3.69 (high). This result shows that most salespersons assume that they already have product knowledge about the products they sell. The highest response was to the statement about "I can convey every information related to the product I offer clearly and in detail" with an average value of 3.78. While the lowest response is in the statement "I already know product specifications well" with an average value of 3.61 .

A salesperson has the primary role in selling each product according to each project following the targets set by the leader. From the beginning, the salesperson at PT Intiland Grande has been given an understanding of each product offered according to their respective projects. The understanding was conveyed through a briefing conducted every day in the morning by each head of each project before conducting sales activities. The briefing will review the salesperson's knowledge of the product to be offered, and discuss the obstacles being faced to what extent the target has been achieved. In addition to the briefing, there is also a product knowledge class that must be followed by all salespersons from all projects when there are new products to be marketed. It does not stop there, but there is also a test for salespersons to find out if they understand every information about the products offered. With this series of activities, the salesperson will be more knowledgeable about their products and be able to convey any information related to the products offered clearly and in detail. Attitudes are evaluative statements, both desirable and undesirable, regarding objects, people, or events [10]. The following is the respondent's response to the statement in the attitude variable.

Table 2 shows that most employees already have a right attitude, as evidenced from the mean of 3.89 (high). This finding shows that most of the salesperson already has a high attitude. The highest response was to the statement about "I am confident in what I am conveying to customers," with an average rating of 4.03. While the lowest response is in the statement "My freedom of thought can help me solve any problem" with an average value of 3.80 . 
Table 2. Descriptive analysis

\begin{tabular}{llc}
\hline No. & Statement & Mean \\
\hline & Product Knowledge & 3.61 \\
\hline 1 & Salesperson possess adequate knowledge about the product specification (PK1) & 3.78 \\
2 & Salesperson is capable of delivering the information about the product offered in & 4.63 \\
\hline & detailed (PK2) & 3.85 \\
\hline & Salesperson own adequate experienced in selling the product (PK3) & 3.80 \\
\hline 1 & Attitude & Salesperson is flexible and feel free in the way of thinking (AT1) \\
2 & Flexibility of the salesperson help salesperson solve the problem (AT2) & 3.81 \\
3 & Salesperson has a freedom in expressing his/her idea (AT3) & 4.03 \\
4 & Salesperson enjoy activities that exercise the creativity (AT4). & 3.59 \\
5 & Salesperson belief in one's idea from the customer (AT5) & 3.85 \\
6 & Salesperson is involved in task assigned (AT6) & 3.66 \\
\hline & Salesperson Performance & 3.77 \\
\hline 1 & Salesperson is active in all task assigned to him/her (SP1) & 3.63 \\
2 & Salesperson always achieve the sale target (SP2) & 3.63 \\
3 & Salesperson capable of delivering satisfaction to the customer(SP3) & 3.80 \\
4 & Salesperson capable of listening and understanding the needs of different customers & 3.86 \\
5 & Salesperson capable of presenting well to attract the customer intention (SP5) & 3.98 \\
6 & Salesperson capable of handling customer needs and desires effectively (SP6) \\
7 & Salesperson capable of creating mutual respect in every sale activity (SP7) \\
8 & Salesperson capable of selling to prospective customers (SP8). & 3.80 \\
\hline 9 & Salesperson capable of achieving sales growth as targeted (SP9)
\end{tabular}

In addition to understanding all information related to the products offered, salespersons are also required to be able to express themselves according to the situation and condition of the customer being faced. Besides, there are also routine activities organized by PT Intiland Grande in order to hone creativity as well as teamwork for all existing employees, such as a potluck competition between projects, routine talk shows by motivators, and so on. Through these activities, it is expected that employees, especially in this case salesperson, can think freely and flexibly in dealing with existing problems. Also, such activities will undoubtedly foster a sense of confidence that is getting better so that every salesperson becomes active in every task that has been given.

\subsection{Salesperson performance}

Behavior of salesperson is demonstrated by how well each salesperson carries out the activities when carrying out the work duties [25]. 


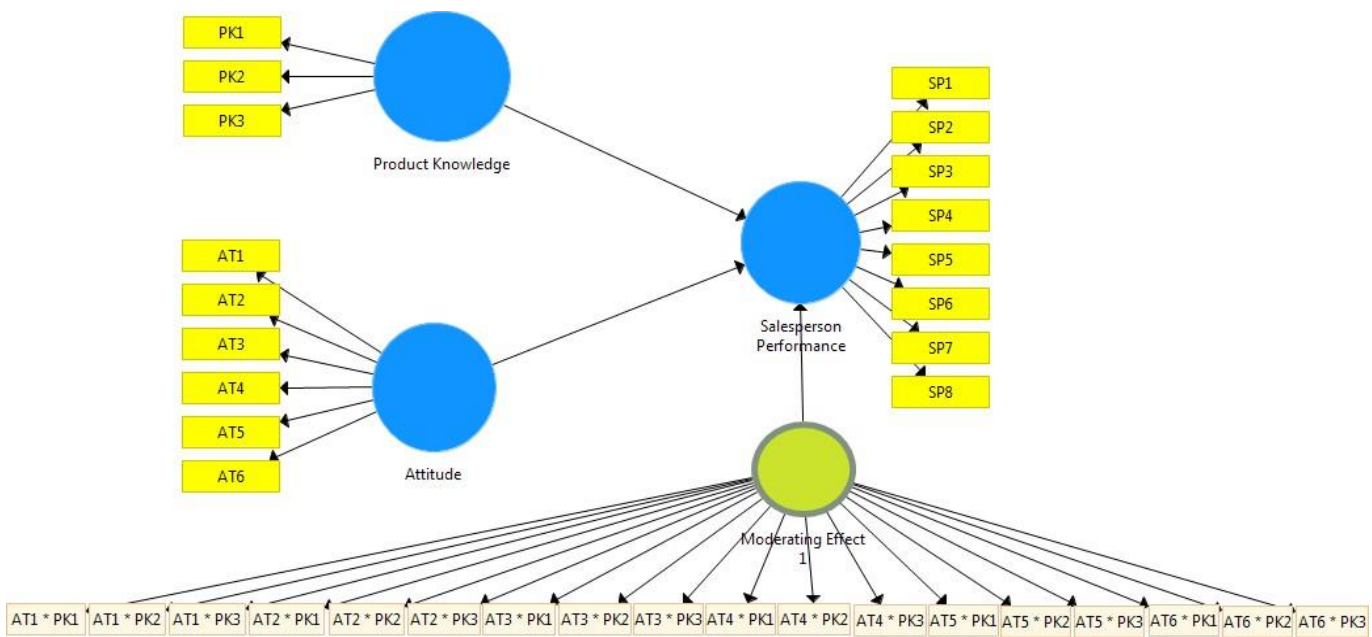

Fig. 1. Research model

Table 2 showed that most employees have salesperson performance in the high mean category. This result shows that most employees already have excellente performance. The highest response was to the statement about "I can sell my product to prospective customers" with an average value of 3.98 each. While the lowest response is in the statement, "I can listen and understand the desires of different customers." With an average value of 3.63. This finding indicates that the salespersons have performed inadequately in understanding Customer desires. The salesperson should performs well in delivering the product knowledge since the customers are not in the same mode in receiving the information. Some customers can receive information quickly, but the rest receive the information slowly. Therefore, in facilitating the delivery of information to customers, PT Intiland Grande salesperson uses existing supporting media, such as brochures, catalogs, to look directly at the show unit as a handling step in meeting customer needs and desires. With that way, the salesperson can do a proper product presentation with the expectation the customer get satisfaction.

Tabel 3. Measurement model analysis

\begin{tabular}{|c|c|c|c|c|c|c|c|c|}
\hline & Attitude & $\begin{array}{c}\text { Product } \\
\text { Knowledge }\end{array}$ & $\begin{array}{c}\text { Salesperson } \\
\text { Performance }\end{array}$ & AVE & $\mathbf{C} / \mathbf{R}$ & C/A & $\mathbf{R}^{2}$ & Remarks \\
\hline \multicolumn{9}{|c|}{ Product Knowledge } \\
\hline PK1 & 0.767 & 0.805 & 0.733 & \multirow{3}{*}{0.680} & \multirow{3}{*}{0.864} & \multirow{3}{*}{0.766} & & Valid \\
\hline PK2 & 0.524 & 0.855 & 0.663 & & & & & Valid \\
\hline PK3 & 0.557 & 0.814 & 0.833 & & & & & Valid \\
\hline \multicolumn{9}{|c|}{ Attitude } \\
\hline AT1 & 0.793 & 0.732 & 0.826 & \multirow{6}{*}{0.693} & \multirow{6}{*}{0.931} & \multirow{6}{*}{0.981} & & Valid \\
\hline AT2 & 0.847 & 0.671 & 0.835 & & & & & Valid \\
\hline AT3 & 0.841 & 0.465 & 0.756 & & & & & Valid \\
\hline AT4 & 0.877 & 0.592 & 0.799 & & & & & Valid \\
\hline AT5 & 0.848 & 0.653 & 0.769 & & & & & Valid \\
\hline AT6 & 0.785 & 0.679 & 0.763 & & & & & Valid \\
\hline \multicolumn{9}{|c|}{ Salesperson Performance } \\
\hline SP1 & 0.767 & 0.805 & 0.833 & \multirow{8}{*}{0.612} & \multirow{8}{*}{0.926} & \multirow{8}{*}{0.908} & \multirow{8}{*}{0.984} & Valid \\
\hline SP2 & 0.527 & 0.605 & 0.663 & & & & & Valid \\
\hline SP3 & 0.557 & 0.614 & 0.699 & & & & & Valid \\
\hline SP4 & 0.794 & 0.739 & 0.829 & & & & & Valid \\
\hline SP5 & 0.847 & 0.671 & 0.853 & & & & & Valid \\
\hline SP6 & 0.735 & 0.576 & 0.756 & & & & & Valid \\
\hline SP7 & 0.576 & 0.435 & 0.799 & & & & & Valid \\
\hline SP8 & 0.635 & 0.715 & 0.806 & & & & & Valid \\
\hline
\end{tabular}




\subsection{Measurement Model Analysis}

Convergent validity indicates the correlation, assessed by the factor loading, between variables and indicators used in measuring the same construct. The indicators are considered valid when the factor loading value greater than 0.5 as the minimum recommended value. Table 3 showed the factor loading of each indicator obtained from the data analysis using smartPLS software version 3.0. All indicators are considered meet the convergent validity in all cases (written in bold). This convergent validity shows that the research instrument used measured what is supposed to be measured. Beside the convergent validity, discriminant validity indicated if the indicator correlated with its variable more than its cross-loading with other variables. Table 3 has demonstrated that the cross-loading of each indicator with other variables are less than its factor loading with its variable. Another measurement for the determinant validity is shown by the square root of the average variance extracted (AVE) for each variable with the value of greater than 0.50 .

Table 3 also shows the result for the indicators reliability. The reliability assessed the accuracy and consistency of a measurement model. The composite reliability $(\mathrm{C} / \mathrm{R})$ and Cronbach's Alpha (C/A) is used to test the reliability of indicators. The minimum recommended value for composite reliability and Cronbach alpha is 0.7 . Table 3 shows that the composite reliability and Cronbach's alpha values are higher than 0.70 in all cases. Thus, it can be concluded that all variables have excellent reliability. This result proves that the measuring model is valid and reliable and the next step for further analysis to test the hypotheses can be continued. Goodness of fit of the latent dependent variable is measured using $\mathrm{Q}^{2}$ predictive relevance for the structural model. This evaluation aims to measure how well the value of the dependent variable is predicted by the model and also the estimated parameters [32]. The Q2 can be assessed by the Equation (1)

$$
\mathrm{Q}^{2}=1-\left(1-\mathrm{R}_{1}^{2}\right)
$$

with the value of $R^{2}$ as shown in Table 3. The result gives a value of 0.984 for $Q^{2}$ of the salesperson performance. Predictive relevance is acceptable for the value of $\mathrm{Q}^{2}$ greater than zero. The result indicated that the research model has a good predictive relevance.

\subsection{Hypothesis testing}

Hypothesis testing aims at determining the correlation or relationship between each constructs studied. Testing the hypothesis in this study using a significance level of $5 \%$ with a statistical t-value of 1.965 (two-tail test). Then the hypothesis acceptance criteria when t statistics greater than 1.96. Table 4 demonstrates the results of a hypothesis testing where one hypothesis (H1) was accepted, and the hypothesis H2 was not supported. Product knowledge has a significant effect on salesperson performance, as evidenced by the $\mathrm{t}$ value of 3.939 .

Table 4. Hipotheses testing

\begin{tabular}{lcccc}
\hline \multicolumn{1}{c}{ Relationship } & $\begin{array}{c}\text { Original } \\
\text { Sample }\end{array}$ & $\begin{array}{c}\text { Standard } \\
\text { Error }\end{array}$ & $\begin{array}{c}\text { T } \\
\text { Statistics }\end{array}$ & Remarks \\
\hline $\begin{array}{l}\text { Product Knowledge -> Salesperson Performance } \\
\text { (H1) }\end{array}$ & 0.390 & 0.099 & 3.940 & supported \\
\hline $\begin{array}{l}\text { Moderation of Attitude on the effect of Product } \\
\text { knowledge on Salesperson Performance (H2) }\end{array}$ & 0.023 & 0.170 & 0.138 & rejected \\
\hline
\end{tabular}

While the attitude of the salesperson does not seem to moderate the relationship between product knowledge and salesperson performance. The finding, product knowledge influences salesperson performance [30]. In daily practice shows that with complete knowledge about a product will enable salesperson to allow customers to decide to buy the 
product in question. Thus it is essential for companies that sell products to customers to equip their salesperson through training on the features and attributes of each product. However, from Table 6 it is also known that attitude does not moderate the effect of product knowledge on salesperson performance because the t value is 0.138 . Thus the hypothesis in this study, which states that attitude moderates the effect of product knowledge on salesperson performance is rejected [15]. Explanation of the rejection of this hypothesis can be explained after having discussions with several respondents wherefrom their explanation it turns out training or debriefing related to behaving or behaving optimistically and confidently is not provided by the company. Thus there is no significant difference between salespersons in carrying out their duties. As a result, there is no correlation between attitudes either weakening or strengthening the relationship between product knowledge and salesperson performance.

\section{Discussion}

The purpose of this study was to examine the effect of product knowledge on salespersons with the presence of attitude as a moderating variable. The results showed that product knowledge had a significant effect on salesperson performance. This is evidenced through the $t$ value of 3.939, which is higher than 1.965. Product knowledge influences salesperson performance. Product knowledge is a salesperson's knowledge of product design and features [3]. Therefore, product knowledge by salespersons will significantly affect the increase in salesperson performance. Salesperson is often a liaison between the company and the customer, and usually, the customer will ask for a product's basic specifications. Therefore, it has become the main task for a salesperson to be able to provide an understanding of the product to customers with specifics and details. Therefore, it is essential that every salesperson has sufficient product knowledge, which enables them to have a high salesperson performance. A salesperson with excellent mastery of product knowledge will have a positive impact on excellent two-way communication between the salesperson himself and consumers. The application of product knowledge is a solution in solving employee performance problems, especially for salespersons, so that the final result will be able to successfully achieve the goals and vision it hopes. The product knowledge has a positive influence on salesperson performance [30].

Based on the previous presentation, it is illustrated that the product knowledge possessed by each salesperson at PT Intiland Grande has been highly adequate. The knowledge initially is obtained during the introduction class held by the company, particularly when a new products introduced to market. Besides, there are also regular briefings held every morning to review the product understanding of each salesperson held by each supervisor of each project. The briefing is very useful for supervisors to monitor the performance of each salesperson. To evaluate the result infield, there is also a small random test conducted to re-sharpen the product knowledge possessed by the salesperson. Finally, the mastery of adequate product knowledge will enhance the salesperson performance. Thus, excellent product knowledge will create good salesperson performance. Also, knowing the products sold, salesperson can create added value for customers.

The second hypotheses states that attitude moderates the influence of product knowledge on the salesperson performance. With the existence of work attitudes and good employee knowledge of the company, it will encourage employees to work better [31]. Nevertheless, based on the results of this study, that attitude did not moderates the effect of product knowledge on salesperson performance, as evidenced by the t-value of 0.138 . This finding proved that attitude neither strengthen nor weakening the relationship of product knowledge on salesperson performance. The reasonable explanation for this finding is the fact that most of the salesperson perhaps have the same background in the society, 
education, and training provided by the company. Hence, most of them have the same level of attitude which already in high category as shown in the descriptive analysis. However, the variance of the performance in correlation with the variance of attitude are not detected by the data collected which may result in that the attitude does not moderate the relationship. This finding does not means that the attitude is not essential for the salesperson. It is crucial to have a right attitude. The attitude of the salesperson determines how to look at work environment, interact with others, and behave at work. Someone with a positive work attitude will like his job and solve problems at work happily, while someone with a negative attitude does not show much enthusiasm and commitment to solving problems. From the beginning, salesperson at PT Intiland Grande was required to have a right attitude, especially in conducting sales activities.

\section{Conclusions}

This study is supposed to examine the effect of product knowledge on the salesperson performance through the moderating role of the attitude. The result indicated that the first hypotheses that product knowledge influence the performance salesperson is empirically supported. While the second hypotheses that attitude moderates the influence of product knowledge on the salesperson performance was not supported. This rejection of the second hypotheses is suspected not due to the salesperson did not required the good attitude but rather because most of the salesperson have the same level attitude (high-level category) hence the variance of the attitude neither strengthening nor weakening the influence of the product knowledge on the sales performance. This finding enhancing the insight of the manager particularly all engaged in property industry that product knowledge is imperative for the salesperson to succeed in their job. This study also contributes to the on-going study in the marketing field. Suggestions that can be given for the company to enhance the salesperson performance is to improve the salesperson knowledge about product specifications. The company may intensify special classes on product understanding, and it will be better if the product knowledge class is carried out routinely, and if necessary, by providing more appropriate tests related to product information mainly for the new salesperson. Therefore, with regular tests, each salesperson will increasingly understand the knowledge related to the design and specifications of each product offered. Other indicator which further intention is the freedom of thought can help the salesperson solve every problem.

\section{References}

1. M.E. Shoemaker, M.C. Johlke, Journal of Managerial Issues, 14,1:118-131(2002). https://www.jstor.org/stable/40604377

2. L. Susaeta, J. Ramón Pin, Idrovo, S., Espejo, A., Belizón, M., Gallifa, A., et al., Cross Cultural Management: An International Journal, 20,3:321-360(2013). https://doi.org/10.1108/CCM-12-2011-0126

3. J.O. Rentz, C.D. Shepherd, A. Tashchian, P.A. Dabholkar, R.T. Ladd, Journal of Personal Selling \& Sales Management, 22,1:13-21(2002). https://doig.org/10.1080/08853134.2002.10754289

4. P. Guenzi, L. De Luca, R. Spiro, Journal of Business \& Industrial Marketing, 31,4:553-564(2016). https://doi.org/10.1108/JBIM-02-2015-0037

5. O. Gök, P. Ersoy, G. Börühan, Journal of Product \& Brand Management, 28,4:475-488(2019). https://doi.org/10.1108/JPBM-10-2018-2054 
6. P. Arte, International Journal of Entrepreneurial Behavior \& Research, 23,6:850865(2017). https://doi.org/10.1108/IJEBR-07-2017-0210

7. R.A. Coulter, L.L. Price, L. Feick, C. Micu, Journal of the Academy of Marketing Science, 33,4:604-619(2005). https://journals.sagepub.com/doi/abs/10.1177/0092070305278512

8. Irianti, N. Jurnal Sains Pemasaran Indonesia, 7,3:335-352(2008). [in Bahasa Indonesia]. http://eprints.undip.ac.id/18357/

9. N.H. Lin, B.S. Lin, Journal of International Management Studies, 2(2), 121132(2007).. http://www.jimsjournal.org/13\%20Nan-Hong\%20Lin.pdf

10. S.P. Robbins, T.A. Judge, Perilaku organisasi [Organizational behavior], Jakarta: Salemba Empat (2008). [in Bahasa Indonesia] http://library.fip.uny.ac.id/opac/index.php?p=show_detail\&id=202

11. T. Soebagyo, H. Subagio, Jurnal Manajemen Pemasaran, 1,2:1-9(2014). [in Bahasa Indonesia]. https://www.neliti.com/publications/133823/analisa-pengaruhstore-image-terhadap-purchase-intention-di-toserba-ramai-ngawi

12. L.G. Schiffman, Consumer Behaviour, USA: Prentice Hall(2002). https://trove.nla.gov.au/work/6251305

13. Y. Mahfud, Journal of Economic, Management, Accounting and Technology, 2,1:107-119(2019). https://ojs.unsiq.ac.id/index.php/jematech/article/view/579

14. A. Ramdhani, D.T. Alamanda, H. Sudrajat, International Journal of Basic and Applied Science, 1,1:33-39(2012). https://core.ac.uk/download/pdf/25714644.pdf

15. Y.L. Kandou, V.P.K. Lengkong, G. Sendow, Jurnal Berkala Imiah Efisiensi, 16,1:147-158(2016). [in Bahasa Indonesia] https://ejournal.unsrat.ac.id/index.php/jbie/article/view/10623

16. V. Rivai, A.F.M. Basri, Performance Appraisal. Jakarta: PT Raja Grafindo Persada (2005). [in Bahasa Indonesia] http://www.rajagrafindo.co.id/produk/performance-appraisal/

17. Sedarmayanti. Manajemen Sumber Daya Manusia: Reformasi Birokrasi dan Manajemen Pegawai Negeri Sipil. Bandung: PT Refika Aditama (2011). [in Bahasa Indonesia]. https://openlibrary.telkomuniversity.ac.id/pustaka/15057/manajemen-sumberdaya-manusia-reformasi-birokrasi-dan-manajemen-pegawai-negeri-sipil.html

18. A. Diamantidis, P. Chatzoglou, International Journal of Productivity and Performance Management, 68,1:171-193(2019). https://doi.org/10.1108/IJPPM$\underline{01-2018-0012}$

19. W.P.K. Darbi, International Journal of Business and Social Science, 3,14:95109(2012).

https://www.ijbssnet.com/journals/Vol 3 No_14_Special_Issue July 2012/11.pdf

20. Wibowo. Manajemen Kinerja. Jakarta: Raja Grafindo Persada (2012). [in Bahasa Indonesia] http://rajagrafindo.co.id/produk/manajemen-kinerja-\%C2\%96-edisiketiga/

21. H. Zameer, S. Ali, W. Nisar, M. Amir, International Journal of Academic Research in Accounting, Finance and Management Sciences, 4,1,293-298(2014). http://dx.doi.org/10.6007/IJARAFMS/v4-i1/630

22. A. Surandini, Jurnal Sains Pemasaran Indonesia, 10,1:88-105(2011). [in Bahasa Indonesia] https://ejournal.undip.ac.id/index.php/jspi/article/viewFile/14142/10737

23. J. Yulianto, Jurnal Sains Pemasaran Indonesia, 1,1:91-106(2002). [in Bahasa Indonesia] https://ejournal.undip.ac.id/index.php/jspi/article/view/13955

24. A. Inyang, R. Agnihotri, L. Munoz, Journal of Business \& Industrial Marketing, 33,8:1074-1086(2018). https://doi.org/10.1108/JBIM-09-2017-0230 
25. A. Baldauf, D.W. Cravens, European Journal of Marketing, 36:1367-1388(2002). https://www.emeraldinsight.com/doi/abs/10.1108/03090560210445227

26. A. Baldauf, D.W. Cravens, N.F. Piercy, Journal of Personal Selling \& Sales Management, 21,2:109-22(2001). https://www.tandfonline.com/doi/abs/10.1080/08853134.2001.10754262

27. R.L. Oliver, E. Anderson, Journal of Marketing, 58,4:53-67(1994). https://doi.org/10.1177/002224299405800405

28. R.M. Hapsari, F. Indriani, S. Sutopo, Jurnal sains pemasaran indonesia, 16,3:145166(2018). https://ejournal.undip.ac.id/index.php/jspi/article/view/17178

29. R.J. Schultz, K.R. Evans, Journal of Personal Selling \& Sales Management, 22,1a:23-31(2002). https://www.tandfonline.com/doi/abs/10.1080/08853134.2002.10754290

30. R.W. Giacobbe, D.W. Jackson, L.A. Crosby, C.M. Bridges, Journal of Personal Selling \& Sales Management, 26,2:115-142(2006).

https://www.tandfonline.com/doi/abs/10.2753/PSS0885-3134260202

31. J. Dongoran, Jurnal Akuntansi dan Manajemen, 17,1:79-92(2006). [in Bahasa Indonesia] https://media.neliti.com/media/publications/111133-ID-pengaruhsikap-kerja-terhadap-kinerja-ka.pdf

32. Ghozali, I. Aplikasi Analisis Multivariate Dengan Program SPSS, [Application of Multivariate Analysis with SPSS Program]. Semarang: BP Universitas Diponegoro (2011).

http://library.fip.uny.ac.id/opac/index.php?p=show detail\&id=3483 